\title{
Peirce on Musement
}

The Limits of Purpose and the Importance of Noticing

\section{Elizabeth F. Cooke}

\section{(2) OpenEdition \\ Journals}

Electronic version

URL: http://journals.openedition.org/ejpap/1370

DOI: $10.4000 /$ ejpap. 1370

ISSN: 2036-4091

\section{Publisher}

Associazione Pragma

\section{Electronic reference}

Elizabeth F. Cooke, «Peirce on Musement », European Journal of Pragmatism and American Philosophy [Online], X-2 | 2018, Online since 11 January 2019, connection on 19 April 2019. URL : http://

journals.openedition.org/ejpap/1370; DOI : 10.4000/ejpap.1370

This text was automatically generated on 19 April 2019.

\section{(c) $(1) \odot$}

Author retains copyright and grants the European Journal of Pragmatism and American Philosophy right of first publication with the work simultaneously licensed under a Creative Commons Attribution-

NonCommercial-NoDerivatives 4.0 International License. 


\title{
Peirce on Musement
}

The Limits of Purpose and the Importance of Noticing

\author{
Elizabeth F. Cooke
}

\section{AUTHOR'S NOTE}

I am grateful to Jerold J. Abrams and two anonymous referees for helpful comments on an earlier draft. Any mistakes that remain are my own.

\author{
"A pretty wild play of the imagination is, it cannot \\ be doubted, an inevitable, and probably even a \\ useful, prelude to science proper." \\ Peirce, "On Science and Natural Classes" (EP1: 131)
}

\section{Introduction}

1 From the beginning of his writings, Peirce establishes pragmatism in opposition to Descartes's subjectivistic philosophy. Whereas Descartes grounds his philosophy in infallible intuition, Peirce grounds thought in an unlimited community of signs and fallible inquiry, which aims at truth and knowledge in the final opinion in the long run. This community of inquiry develops teleologically, in Aristotle's sense, toward this one goal of knowledge, and this goal seems to draw all rational inquiry toward completion. If individuals come together with a commitment to truth and an openness to error, then the community can and will achieve truth in the long run. Peirce grounds this view in the assumption that our minds are evolutionarily attuned to nature and this attunement, if unfettered, draws our guesses toward knowledge of nature. Peirce calls these guesses "abductions." Abduction is a distinct form of inference and operates at every level of experience from everyday perception to the most ingenious scientific theory and it generates all new ideas.

But as Douglas Anderson demonstrates in Strands of System: The Philosophy of Charles Peirce, Peirce holds that abductive inferences, which aim at the final opinion, depend on a more 
subjective, and far less organized, thought process called "musement" (Anderson, 1995: 146-7). Peirce develops this theory of musement especially in his late essay, "The Neglected Argument for the Reality of God" (1908, hereafter NA), where he defines musement as "pure play," and recommends this form of thinking not for the sake of truth, or problem-solving, or any purpose at all, but merely for recreation. In the NA Peirce establishes musement as the enjoyable, purposeless, meditative, free, creative, and contemplative mode of mind. Peirce also recommends practicing musement at a peaceful time of day, morning or evening, which encourages the mind naturally to generate those ideas found within its depths, and corresponding to nature, and among these is the idea of God.

3 But the theory and practice of musement is by no means limited to Peirce's philosophical theology, as Anderson also writes, but lays at the center of his philosophy. In fact, Peirce emphasizes the need for free creative imaginative play in philosophy and science throughout his writings. For example, in the epigraph above, from "On Science and Natural Classes," Peirce writes: "A pretty wild play of the imagination is, it cannot be doubted, an inevitable, and probably even a useful, prelude to science proper." Indeed, while Peirce developed his theory of free play at length only in his very late work, his first entry into philosophy was this very theory of aesthetic play, which he found in Friedrich Schiller's Æsthetical Education of Man (1794) with the concept of "Spieltrieb" (play drive). ${ }^{1}$

4 Peirce holds onto this notion of play and develops it in relation to his theory of inquiry, but renames Schiller's "Spieltrieb" "musement," after the Greek "Muse," thereby capturing pure play's poetic dimension of inspiration. ${ }^{2}$ In Greek mythology the Muses are goddesses who control inspiration, genius, and creativity in all the arts and sciences. Peirce describes the practice of musement in much the same way great poets like Homer, Virgil, and Dante describe their engagements with the Muse as passive, powerful, and inspired. But, in some contrast to these poets who claim to hear and record the divine song of the Muse, Peirce finds musement to be the first stage not just of rare poetry but of the evolution of many new ideas in science. Musement as the somewhat passive but free play of mind contains absolutely no purpose, yet undergirds all purposeful advancement in the community of inquiry, since musement supplies inquiry with its novel insights. So the pragmatist theory of inquiry, defined primarily by its teleological end, appears to be grounded in a most unteleological thought process.

The question for this paper is whether we can rationally control musement even though it has no purpose other than recreation. In the first part of the paper, I argue that in musement, precisely because she eliminates all purpose from the mind, the muser is able to notice new signs, anomalies, problems, and questions, which allows her to generate novel hypotheses by speculating about these newly noticed things. Musement is about opening oneself up to new problems and anomalies, as well as opening oneself up to new explanatory hypotheses.

6 Here three stages of musement, implied in Peirce's discussion, should be distinguished:

(1) The pure play of ideas in which the individual is passive to ideas entering her mind, and thus open to noticing new things, which is akin to Peirce's phenomenological category of Firstness, the spontaneity of feeling;

(2) noticing strange phenomena, which is akin to Peirce's category of Secondness, or reaction; and 
(3) the creative formation of an hypothesis that explains a strange phenomenon, and which then can be used in abduction, which is akin to Peirce's category of generality or Thirdness.

7 While many commentators focus on the third stage of musement, I will focus on the first and second stages. In the second part of the paper, I argue that while we cannot directly control the reception of new ideas, we can indirectly control the purposeless and free play of musement insofar as we control when, how, and how deeply we engage in this practice; and further we consciously choose our ideals prior to musement, which end up bearing on which novel phenomena we notice in musement. This discussion of the evaluative and thus rational aspect of noticing itself is largely absent in the literature on Peircean musement and can help explain why some people notice problems, wonders, and anomalies, while others do not.

\section{2. "Evolutionary Love": Musement's Role in Peirce's Cosmology}

8 The Muses are thought to inspire great poetry, and they come when they will, not when poets will that they come. Indeed, if the poet seeks to control the Muses, inevitably he fails. As Peirce writes in "Evolutionary Love" (1893), in the Monist series (1891-1893),

It is as easy by taking thought to add a cubit to one's stature, as it is to produce an idea acceptable to any of the Muses by merely straining for it, before it is ready to come. We haunt in vain the sacred well and throne of Mnemosyne; the deeper workings of the spirit take place in their own slow way, without our connivance. (EP1:361)

Here again, as in "On Science and Natural Classes," Peirce develops his Schillerian theory of play that will become "musement" in the NA. In fact, here in "Evolutionary Love," Peirce identifies the same state of free and open and relaxed contemplation as the ground of new ideas, with the Muses and their mother Mnemosyne Greek goddess of memory. But here too Peirce writes, as so many others have written of genius and inspiration, like Homer, Plato, Virgil, Dante, and Popper, that creativity is not within our control.

And yet, in this same discussion in "Evolutionary Love," Peirce also suggests that the activity of play might partly fall under our control. While we may not be able to "strive" for an "idea acceptable to the Muses," we can initiate play by striving to break up old habits of thought, in the imagination; and we can alter our surroundings so that the mind is open to new surprises which brightens ideas (CP6.301/EP1:361). Most of the time, the mind works almost mechanically, sinking into the condition of a railway junction, but here in play there appears a "spiritual peninsula, or cul-de-sac" (EP1:361). ${ }^{3}$ In this way, by breaking up habits and engaging in play, the mind exercises some preliminary control over the reception of new ideas. Because this activity is consciously directed, Peirce - in his otherwise Darwinian theory of mind - identifies the play of thought with JeanBaptiste Lamarck's teleological theory of evolution in Philosophie Zoologique (1809): “Thus, the first step in the Lamarckian evolution of mind is putting of sundry thoughts into situations in which they are free to play" (EP1:361).

It should be noted, however, that one of Peirce's points in "Evolutionary Love" is that the individual is not as important as the community in coming up with new ideas. So here Peirce ultimately argues for what he calls an agapastic view of the evolution of thought, 
which emphasizes the individual, and emphasizes the importance of the evolving collective thought of society and the age, generating creative ideas (EP1:369; see also 370-1). While a more social or intersubjective mode of musement also appears to operate in Peirce's philosophy, appearing prominently here in "Evolutionary Love," this mode of musement must be set aside for purposes of the present discussion. By contrast, a much more individualistic account of musement appears in the NA, and this account will help us to address the question of rationally self-controlled play.

Still, individual creativity operates within this evolutionary account of mind, developed in "Evolutionary Love." The deeper workings of the spirit operate in the community and evolve through history in their own slow way. But these deeper workings ultimately house themselves in the individual minds who produce all the creative works of the arts and sciences. Valuably filling in this picture of agapastic creativity, Anderson in Creativity and the Philosophy of C. S. Peirce advances what he finds to be Peirce's implicit view of artistic creativity and the kind of rational self-control operative within this thought process. According to Anderson, Peirce's cosmological principle of agape is the principle of control in God's ongoing creation of the evolving cosmos, and that it serves as an analogy for Peirce's view of human creativity (Anderson, 1987: 109). Anderson argues that, for Peirce, an artist controls the creative process by virtue of love for his art which he allows to grow under his care, like a garden. Anderson (ibid.) quotes Peirce saying, "The agapastic development of thought is the adoption of certain mental tendencies, not altogether heedlessly, as in tychasm, not quite blindly by the mere force of logic, as in anacasm, but by an immediate attraction for the idea itself, whose nature is divined before the mind possesses it, by the power of sympathy, that is, by virtue of the continuity of mind [...]" (CP6.307). Agape allows an attractive idea to evolve and grow on its own terms (Anderson, 1987: 110). These are the cosmological principles which can make sense of both God's and humanity's creative rational control. As Anderson writes, “ Agape thus mediates for creativity between purely tychistic and anancistic processes which Peirce saw as the traditional alternatives. An artist loves his idea and develops it by letting it suggest its own perfection" (ibid.: 134).

The present view fits within Peirce's cosmology, as Anderson describes it, but shifts focus from the cosmology in "Evolutionary Love," which Anderson ascribes to Peirce's more phenomenological account. Peirce sets his phenomenology and categories at the ground of his philosophy, and these appear in every dimension of his thought, drawing these categories with one eye on Aristotle and the other on Kant. As Aristotle laid his own ten categories of being at the center of his philosophy, and Kant established his four categories of the understanding as shaping all possible experience, Peirce establishes his own three categories of Firstness, Secondness, and Thirdness, as operative throughout the entire universe, which (contra Kant) is knowable in itself. And in contrast to Aristotle in Physics II.8, and following Darwin's Origin of Species (1859), Peirce found the mind to have been shaped by millions of years of evolution, so that Peirce's (more Aristotelian) categories of nature reappear within the mind. But once these Aristotelian categories of nature reappear in new form by evolution within the human mind, they take on a more Kantian dimension. The spontaneity of nature also reappears within the mind, and this now Kantian spontaneity of mind shapes perception and experience according to the categories of the mind, categories which exhaust all possible experience. The spontaneity (fortuitous variation) manifests itself most prominently within the mind as the free creative play of musement. In examining musement, then, we cannot entirely separate 
mind from nature, for the play of musement is an extension of play in nature, in much the same way Anderson argues human artistic creativity is an extension of spontaneity in nature.

Yet, in musement, these categories may be interpreted in two ways, which stem from the two main historical and philosophical sources of the categories, namely, Aristotle and Kant. If we take a more Aristotelian approach to Peirce's theory of musement, then musement appears to be the cultivation of natural spontaneity and teleological movements, and this more Aristotelian approach appears in Anderson's more cosmological discussion of musement. For example, as Anderson writes, the mind tends its phenomena like a gardener tending a garden, where spontaneity, variation, complexity, beauty, and teleology all intertwine, and the function of the gardener, or inquirer, or muser, appears to be one of an artistically skilled and creative hand who respects the creativity of nature already operating within her mind, as in nature. Ideas unfold and bloom by equal parts good cultivation and wise moderation.

On the more Kantian view, which I am advancing, the gardener similarly tends her garden with many of the same techniques, the same categories, the same phenomenological and pragmatist eyes as the Aristotelian gardener. But the Kantian pragmatist gardener freely imposes more of herself into nature, with her own ideals. What she sees in the garden of her musing mind is partly given by nature, but largely shaped by the imposition of her own creative mind. Peirce began his philosophical career as a Kantian transcendental philosopher, but then, partly in response to Darwin, Peirce moved to a more Aristotelian metaphysics of potency and act, and an evolutionary objective idealism. Still, these two major systems of philosophy continued to mix in complex ways throughout Peirce's writings, and while some may find him to unfold more of what is often taken to be a "pragmatist" philosophy, rather than a Kantian philosophy, Peirce's theory of musement, advanced in his later years, arises out of his very early studies in Schiller's aesthetics of play, in relation to Kant's theory of the imagination. And musement still bears the marks of a very Kantian mindset, even while incorporating a quite Aristotelian view of aesthetic contemplation, as found in the Nicomachean Ethics X.

Next we examine Peirce's account of rational self-control, and then examine whether musement may fit this description.

\section{Self-Control in "What Makes a Reasoning Sound"}

17 In "What Makes a Reasoning Sound" (1903) Peirce defines self-control as conduct regulated by one's ideals. An individual has a certain ideal based on the aesthetic quality it has for the individual, a consistency with other ideals, and the aesthetic quality of the consequences she imagines of fully carrying out her ideal (EP2:245-6). Upon reflecting on his ideal, the inquirer seeks to make his conduct conform to this aesthetic ideal. So, he formulates rules of conduct, which have an effect upon his disposition so that he modifies what he is inclined to do (EP2:246-8). He forms resolutions about how he will act under certain anticipated occasions, and, according to Peirce, "This resolution is of the nature of a plan, or, as one might almost say, a diagram" (EP2:246). If the anticipated occasion actually arises, and the individual acts, then afterward, the individual examines (approvingly or disapprovingly) how his actions compare with his ideal, and these judgments will then affect his future actions (EP2:247-8). A man will review his conduct and his ideals repeatedly throughout the course of a life (EP2:248). ${ }^{4}$ It is worth noting 
here that one may very well need creativity in conceiving of an ideal in the first place, just as one would most certainly need imagination in considering the anticipated occasions one would compare with one's ideal. This suggests that creativity may be prior to self-control, and therefore not subject to it. I will have more on this point in the final section.

\section{Musement as the Purposeless Free Play of Ideas}

In the NA Peirce defines musement as follows:

There is a certain agreeable occupation of mind which, from its having no distinct name, I infer is not as commonly practiced as it deserves to be; for, indulged in moderately, - say through some five to six percent of one's waking time, perhaps during a stroll, - is refreshing enough more than to repay the expenditure. Because it involves no purpose save that of casting aside all serious purpose, I have sometimes been half-inclined to call it rêverie, with some qualification; but for a frame of mind so antipodal to vacancy and dreaminess, such a designation would be too excruciating a misfit. In fact, it is Pure Play. Now, Play, we all know, is a lively exercise of one's powers. Pure Play has no rules, except this very law of liberty. It bloweth where it listeth. It has no purpose, unless recreation. (EP2:436)

"Pure play" is a practice which aims at nothing outside itself and is done for its own enjoyment, for recreation alone. And it is not practiced frequently enough. Unlike the play of a game, there are no purposes or rules in pure play, or musement, except the one law of liberty. Peirce confesses to a temptation to call play "rêverie," but retracts that name because it suggests vacancy. Like Schiller's Spieltrieb, Peirce's musement is intellectual free play without form or hindrance, performed for the sake of pleasure. After defining musement as free play, Peirce then quotes John 3:8 in the Bible: "It bloweth where it listeth." ${ }^{5}$ This quotation, in Peirce at least, suggests a passive dimension to musement as well as a religious dimension, consistent with the purpose of the essay, "A Neglected Argument for the Reality of God," in which Peirce argues that musement "will in time flower into the N.A." (EP2:436). The more passive, though not vacant, perspective of musement would seem more consistent with Anderson's, what I am calling, more Aristotelian view, where musement does what it does, and the gardener functions to allow musement as a fertile intellectual garden to "flower into the N.A."

Because musement must be free, there is, for Peirce, no single way to engage in this practice. Musement "may take either the form of esthetic contemplation, or that of distant castle-building (whether in Spain or within one's moral training), or that of considering some wonder in one of the Universes [of signs] or some connection between two of the three, with speculation concerning its cause" (EP2:436). It is this last kind of play which Peirce calls specifically the "play of musement," in which the mind is naturally led to the hypothesis of God for its natural aesthetic attractiveness. In musement one follows questions and ideas wherever they may lead, suggesting a thought process cultivated with an openness to wonder and anomalies. Yet Peirce thinks most people tend to begin musement with psychological questions, which often lead to musings on variety among the universes, and then continuity among them, finding in these universes of signs the phenomenon of evolution or growth, the growth of signs themselves. And then, reflecting on growth of signs in the three universes, whether or not the muser be consciously contemplating the concepts Peirce articulates, Peirce claims that anyone may arrive at the hypothesis of the reality of God, and will be stirred to the 
depths of her nature by the beauty of that idea, and by its practicality, to shape one's conduct into conformity with it, i.e. to believe it (EP2:440). Peirce's third-person account of musement in the NA can still appear deterministic, since Peirce describes musement as almost destined to end in a hypothesis about God. But Peirce also insists that musement is a practice in which one can decide to engage, suggesting that it is within our control (EP2:436).

While it is important to articulate the context of the NA in which the theory of musement appears, it is no less important to bear in mind the centrality of that theory to the whole of Peirce's philosophy. In fact, even in the religious context of the discussion in the NA, Peirce claims that play may function as part of the first stage of inquiry of which abduction is an essential part (EP2:440-1). And again, as Peirce writes in "On Science and Natural Classes," science depends on "a pretty wild play of the imagination." In fact, even in "The Fixation of Belief" (1877) musement operates as a condition of inquiry. As Anderson writes in Strands of System, while Peirce often uses Romantic and poetic imagery to describe it, ultimately musement plays a fundamental role in the basic structure of inquiry.

In less romantic terms, this underdetermination in musement can also be seen as a condition of the scientific method of 'The Fixation of Belief'; it is the only method that does not begin inquiry with its goal already presupposed. Musement is an activity in which we may choose, in a self-controlled fashion, to engage, but it leaves room for tychistic development, for ideas 'to grow up spontaneously out of Pure Play without any breach of continuity.' (Anderson, 1995: 146) ${ }^{6}$

Science and its various stages of inquiry all have their goal presupposed, but all rest on musement, which does not have its goal presupposed. We can control musement, according to Anderson, at the beginning with the choice to enter the state, but this control is not very great, for in musement ideas must be free to rise up in the mind spontaneously (tychistically). ${ }^{7}$ Anderson takes up the question of control in musement again in relation to abduction, and again describes the activity of musement as play that begins with control but does not proceed with control. As Anderson (1995: 157) writes,

[...] while retroduction is self-controlled, this first moment of critical reasoning is not fully controlled. There is a spontaneous dimension; the reasoner controls to the point of permitting the play of ideas but then must respond to retroductive suggestions as they present themselves.

Here Anderson establishes the precise interval of control in Peirce's theory of inquiry between musement and abduction. The inquirer, by an act of conscious self-control leaves controlled inquiry and enters the open and playful state of musement, and then emerges from the free play of ideas with an insight utilized in controlled inquiry.

Of course, Peirce holds that scientific inquiry is a rational, self-controlled, and purposeful activity, which aims at truth in the long run. So, it appears that the purposeful activity of inquiry ultimately arises from the purposeless but creative activity of play. That relationship and apparent tension raises the question whether play can be controlled at all, beyond "permitting the play of ideas," especially if it has no purpose. 


\section{Thinking without Purpose Enables One to Notice Novelty}

make sense of a thought process which has no purpose, especially considering that, for Peirce, all thought is in signs, and all signs are end-directed. As T. L. Short argues that semiosis is always teleological, for Peirce (Short, 2004: 230). In conscious thought, a sign prompts a trajectory of thought insofar as a sign represents an object (in a certain respect and for a certain purpose) to an interpretant, so all thought is purposeful insofar as it is interpretive..$^{8}$ Of course, musement is thought in signs, and signs are teleological, and this teleology appears in the phenomena of growth in musement, and yet musement is purposeless. But musement must have at least some purpose in order to be meaningful at all, in order to be semiotic at all, and to bear the fruit that it does. Peirce must mean that musement does not have a set-out agenda or plan, as we might have when we set out to plan a vacation, prove a theory, grow flowers, or paint a painting.

Perhaps we can understand the purposelessness of musement in this way. In discussing associations of the mind, Peirce explains that when we say that some thought has occurred to us, that thought does not actually enter consciousness. Rather, for Peirce, the thought is already there in consciousness and only seems to enter into consciousness when the thought becomes semiotically connected with another idea in a voluntary act of reasoning, and so becomes subjectively vivid enough to "find a place in our narrative" (CP7.435). Now if a voluntary act of thought (i.e., a purposeful one) makes some ideas, which are already there in consciousness, more vivid, then trying to get rid of purpose, as we do in musement, might make many more of our ideas vivid at once, or make some ideas less vivid, thereby allowing other ideas to become more vivid. Whether novelty comes from new experience or from exploring what is already there in one's mind, but which has not yet found "a place in our narrative," musement's purposelessness seems to offer the benefit of allowing potential ideas to become actual when they otherwise would not have, due to our previous purposes holding the reins.

Also central to understanding musement as purposeless is the question whether the wonder, which becomes the focus of musement, initiates musement, or results from musement. Admittedly Peirce in the NA says musement begins with "considering some wonder in one of the Universes or some connection between two of the three, with speculation concerning its cause" (EP2:436). But it is not clear whether Peirce means that one sets out to muse about a wonder (and its cause), or whether one considers a wonder, and then in the process of musement, begins to speculate about its cause, or, as a third possibility, whether one sets out to muse and then, through this process, notices the wonder and begins to speculate about its cause. There are significant differences here. For example, if one sets out to muse about a cause of a wonder, then musement already has the purpose of finding a cause. And even if one simply begins to muse about a wonder, musement would already have a focus, something already deemed to be a wonder or a curiosity worthy of speculation, and this too would give musement a purpose. But if one sets out to think for no particular purpose, and, in doing so, certain wonders, surprises, and anomalies naturally come up, then this activity better fits Peirce's description of musement as performed for the sake of recreation, and without a particular purpose, but which may gain a purpose through this open thought process.

European Journal of Pragmatism and American Philosophy, X-2 | 2018 
Within this purposeless activity, the muser lays open her mind to noticing and identifying a wonder or a surprise worthy of subsequent speculation as to its cause and nature. This view makes the most sense of Peirce's comments on musement.

Peirce claims that inquiry begins with surprises which we seek to explain and understand (EP2:440-1). Peirce also includes the noticing of a wondrous phenomenon in this first general stage of inquiry, which means that noticing strange phenomena is part of the creative hypothesis-generating part of science (EP2:441). In this way, musement as an openness to surprise and to noticing wonders can be seen to function as a condition for inquiry. And Peirce's discussions on musement suggest that creativity is not only about problem solving whereby the creative work is done within the narrow parameters of the problem at hand, but that creativity is often about noticing, which allows one to find a good (important or interesting) problem upon which to speculate in the first place. This is an important dimension that is overlooked in many accounts of creativity. ${ }^{9}$

\section{Entering Musement}

In his early anti-Cartesian papers Peirce rejected the subjectivist and detached view of mind, which John Dewey in The Quest for Certainty (1929) would later call the "spectator theory of knowledge" (Dewey, 2008: 19). Perhaps nothing could be more antithetical to pragmatism than this view of the mind as a disengaged spectator, and yet something like this view appears to be what Peirce sets at the center of his philosophy with musement. In one of the most poetic passages of the NA, Peirce describes musement as deeply passive and spectatorial, and yet also dialogical.

'Enter your skiff of Musement, push off into the lake of thought, and leave the breath of heaven to swell your sail. With your eyes open, awake to what is about or within you, and open conversation with yourself; for such is all meditation.' It is, however, not a conversation in words alone, but is illustrated, like a lecture, with diagrams and with experiments. (EP2:437)

A skiff is a light and small boat, typically with a flat bottom. A skiff has no rudder and no motor, but can have a sail to be blown by the wind. We enter our skiff, according to Peirce, we take in our oars, and push off into the lake of thought. We give up control and allow musement (like the wind) to take us where it will. Peirce calls this activity a meditation and conversation with oneself, which suggests a rational thought process, with some level of control over the activity. Peirce also describes the muser's conversation not only in words but illustrated with diagrams and experiments "like a lecture." But it is not clear whether she is giving or receiving a lecture, and it is not clear whether she is constructing and interacting with her own diagram or receiving it.

In support of musement as dialogical, but somewhat passive, Michael Raposa in Peirce's Philosophy of Religion argues it is also a kind of listening. ${ }^{10}$ Raposa claims that in musement the individual should be attentive and fully awake, listening with lively attention, to the back-and-forth of passive and active thinking, like the give-and-take of actual conversation (Raposa, 1989: 210). But in entering this thought process, one treats one's previous beliefs and concepts in a detached way, "as though one did not have them," which thereby allows one to treat the contents of the mind playfully (ibid.: 215). Kathleen Hull in "Why Hanker After Logic? Mathematical Imagination, Creativity and Perception in Peirce's Systematic Philosophy," emphasizes the visual over the verbal nature of musement, but similarly argues that in musement we must inhibit the self in order to 
perceive "the spontaneous conjectures of instinctive reason," and then observe nature, or our diagrams, in a more self-controlled way, where we will see correctly and arrive at necessary perceptions (Hull, 1994: 289-90).

Raposa's listening interpretation, and Hull's visual interpretation, both appear in Peirce's NA, and I follow both interpretations, as well as Anderson, in portraying musement as partly passive. But, as these commentators view musement as a process of generating, contemplating, and selecting hypotheses, we also extend this passive listening and attentiveness of musement to include the noticing of phenomena as strange and anomalous from the start. The process of musement includes a kind of openness to puzzles, surprises, and anomalies that are in need of explanation, in addition to generating and selecting hypotheses. On my view, musement not only opens us up to discovering solutions to problems (because it opens our minds to possibilities beyond our current beliefs), but also opens our minds to problems and constraints that were not previously noticed or appreciated, and thereby gives us new wonders about which to hypothesize.

In "On the Algebra of Logic" (1885) Peirce writes that thinking is prompted by irritation and stimulation (CP3.155), but surprise need not arise externally - one can also experience surprise internally from a fancy, from our own imagination, which can begin a train of thought (CP3.159). ${ }^{11}$ In musement one opens oneself up to experiencing, either from fancy or the world, new surprises that might otherwise go unnoticed and unfelt. So musement includes the initial process of opening oneself up to being surprised and to noticing strange, surprising, wonderful phenomena, and the speculation about explanations, and the generation of hypotheses.

\section{The Importance of Noticing}

34 The first moment of abduction is the appearance of a surprising or strange phenomenon. And we do not need to muse in order to notice a strange phenomenon and then creatively form an abduction. In fact, we creatively form abductions all day long. But we miss things and fail to make abductions all day long as well. Musement is ideal for noticing strange and surprising phenomena that might otherwise go unnoticed. It is important that we open ourselves up not only to strange things, but also to wondrous things, and wondrous things that are familiar but under-appreciated or previously unnoticed. In "The Universal Categories" (1903) Peirce implies a need for the kind of openness to new wonders we find here in musement when he argues that sometimes the truly wondrous things are the familiar things that typically go unnoticed in favor of the more obviously strange or different.

[...] [T]he Faradays and Newtons seem to themselves like children who have picked up a few pretty pebbles upon the ocean beach. But most of us seem to find it difficult to recognize the greatness and wonder of things familiar to us. As the prophet is not without honor save [in his own country] so it is also with phenomena. Point out to the ordinary man evidence, however conclusive, of other influence than physical action in things he sees every day, and he will say: 'Well, I don't see as that frog has got any points about him that's any different from any other frog.' For that reason we welcome instances perhaps of less real cogency but which have the merit of being rare and strange. (CP5.65)

Most of us walk upon the beach and think nothing of a pebble or a frog. But the great scientists like Faraday and Newton look at common and everyday things and see them as 
strange and marvelous. Their minds seem to live in a more childlike and playful state. Peirce thinks of musement as precisely this frame of mind for noticing the miraculous in the common. Noticing great and wonderful things can be difficult because often they are so familiar and because the mind becomes habituated to seeing them all the time. But in musement the mind is open to considering the most common and everyday features anew. And sometimes when we do this, even familiar things can all of a sudden be noticed anew and felt even as surprising and wondrous.

Now abduction depends not just on having the initial surprise but also on feeling its need for an explanation. As Peirce writes in "On the Logic of Drawing History from Ancient Documents, Especially from Testimonies" (1901),

Abduction makes its start from the facts, without, at the outset, having any particular theory in view, though it is motived by the feeling that a theory is needed to explain the surprising facts. (EP2:106)

Abduction begins with a strange or surprising phenomenon. And musement is the process of opening oneself to such surprises and anomalies and to the feeling that a theory is needed to explain the surprising fact. (And, again, the mind in musement doesn't just begin with an openness to questions, but is open throughout, following the ideas, anomalies, surprises and questions wherever they lead.) So creative thinking in musement is not just a kind of dialectic which answers questions, but one that finds and raises questions. And it seems we are aesthetically motivated in musement since we engage for the sake of recreation alone, for pleasure. So, if we are interested in fostering this kind of creativity that yields novel problems and questions, then it seems we have to foster a kind of enjoyment of open-ended and purposeless thinking.

Again, we cannot control receiving novel ideas by simply striving for them, as Peirce writes in "Evolutionary Love." And the surprise which prompts inquiry itself cannot be controlled, since it does not make sense to say that one can set out to be surprised. But we can try to leave ourselves open to new and interesting surprises. And if we do this while attempting to neutralize our current beliefs and traditions, as Raposa (2012b: 52-3) writes, then we may come upon surprises which prompt new lines of inquiry and hence new ideas. Of course, we can have no guarantees that we will see strange and surprising phenomena, and yet, as Peirce writes of abduction, the mind is adapted to see and know the world. Only, the mind must detach itself from its everyday habits of looking at the world in order to see it better.

\section{Is Musement Self-Controlled?}

Now we must consider whether musement is more in line with rational self-control or whether it lies beyond our control, like perceptual judgments. For Peirce, in "What Makes Reasoning Sound," reasoning "is essentially thought that is under self-control, just as moral conduct is conduct under self-control" (EP2:249; see also EP2:188 and 337). And this is why Peirce regards reason as a part of ethics. In the same way that we evaluate actions according to ideals, we also evaluate reasoning according to ideals, continually checking, evaluating, and approving our thoughts (like our actions) as rational (EP2:249-50). But thought must be checked and deliberately approved to be called rational (EP2:250). An operation of the mind is considered reasonable, if there is an ideal to which a person compares his thinking when it is done. If an activity of the mind is rational and selfcontrolled, then this means that it is also a conscious operation, as Peirce writes in 
"Issues of Pragmaticism" (1905, EP2:348) and "The Basis of Pragmaticism in the Normative Sciences" (1906, EP2:387). But there are limits to self-control in thought and in inquiry, as we do not exercise control over perceptual judgments or our already established beliefs (EP2:387; see also 169, 240-1, 337).

Raposa, Hull, and Roberta Kevelson in Peirce and the Mark of the Gryphon, all claim musement is a kind of reasoning, which would mean that it is self-controlled. ${ }^{12}$ Yet, this implication does not seem to be central to Peirce's own discussion of musement. And further, there are at least two reasons why musement would appear not to be rationally self-controlled. First, as we have already discussed, musement does not have a purpose initially, except for the purpose of musing itself. It proceeds throughout in a very openended way, taking up problems and leaving them for new ones, following ideas wherever they lead. The second reason follows from the first, namely, that there is no possibility for error in musement, in contrast to inquiry, in general. ${ }^{13}$ In musement the free-playing mind cannot go wrong because it does not aim at anything in particular.

41 For these reasons, on our view, musement does not fit neatly into this model of rational self-control. But as we shall argue in the next section it does fit there loosely because, within musement, even while it is passive, we still evaluate and make judgments for good reasons.

\section{Musement as Internally Rational Yet Without Purpose}

While our focus has been on musement as an initial stage of creativity in science, art, and even everyday thinking, Anderson's discussion on the rational control of artistic creativity remains a helpful guide. In Creativity Anderson claims that, for Peirce, "as an artist creates, his telos gets refined. It grows and becomes more and more distinct. Thus, in the same way that for Peirce the universe itself moves from the vague to the definite, an artist's telos crystallizes in its unique particularity" (Anderson, 1987: 5-6). For Anderson, the artist does not have full rational control of his activity and the activity may not even be his, but the control the artist has is in developing a telos and letting it grow under his care (ibid.: 6). ${ }^{14}$ But artistic creativity can be seen as rational, despite the artist not knowing where he is going initially, because he tends to his work, engages it, and has agapastic concern for it.

Following Anderson, I also argue that, even in the initial stages of creative musement, the play of ideas which enables us to notice new things can also be seen to be rational, although it begins without purpose, but for the following distinct reason: musement seems to be evaluative through and through. And if it is evaluative, then musement must appeal to an ideal. And if it consciously appeals to an ideal, then musement can be said to fit loosely into Peirce's model for rational self-control.

Creativity often includes noticing interesting and important phenomena to consider, which requires evaluation and appealing to ideals. But not only is there evaluation in selecting which feature of reality on which to focus one's speculation, for even the very having of surprising experience or the very noticing of wondrous or anomalous phenomena can be thought of as evaluative insofar as a surprising experience is influenced by what we know and what we value. Some things strike one person as surprising, while another person who experiences the same thing is not struck by the 
experience (and therefore really has a different kind of experience), and does not judge it to be anomalous because she differs in her knowledge or values. We typically cannot help but form expectations, some of which will be disappointed, and thus cannot help but be surprised. But which experiences are surprising will differ for different people. If, for example, a person does not know that camels are mostly a desert animal, then she probably would not feel surprised to learn that camels can swim. ${ }^{15}$ But it is also the case that if a person knows, but does not care, about desert animals, or does not care about what animals can or cannot do, then she may not experience surprise upon seeing camels swim. While we all experience surprise pervasively throughout our everyday experience, for Peirce, we are surprised about different things (CP1.332). Our beliefs and our cares partly constitute our expectations about the way the world is. These beliefs, cares, and values are normative and descriptive, and they function to prime the pumps of perception for experiencing different kinds of surprises throughout one's day-to-day experience. When one lacks care or belief, some potentially surprising signs are not recognized or felt as surprising, and thus cannot initiate further thought.

But do cares and values function like ideals in Peirce's account of self-control? Ideals, for Peirce, are chosen, and have a regulative effect on the individual, whereas one may care or value something without having chosen these as her ideals. Nonetheless, often cares and values do indicate a chosen ideal. For example, because a mother cares, she might notice (and be surprised by the fact) that her daughter is missing her lunchbox on her way to school. The mother's noticing indicates her cares and values, but this also indicates an ideal she holds, namely, that her daughter eats all her meals. The surprise reveals to her not just her previous beliefs, which are sometimes held unconsciously, but also her ideals and values, which are not unconscious, but which might not have been initially at the forefront of her consciousness at the moment when she notices the missing lunchbox. Still her ideals and values are there. Similarly, throughout the different stages of musement, we engage our previous beliefs, values, and ideals as we face new ideas and experiences, even though we did not set out to fulfill our ideals when we set out to muse.

But is this still reason if we did not set out to fulfill a goal? While musement may not begin with a plan or purpose, nonetheless reasons are internal to the thought process. Even at the initial stage, the muser has reasons for noticing something as anomalous and experiencing it as surprising insofar as she can rationally explain why she felt or took something to be surprising in relation to her previous expectations - even if she did not know what her previous expectations were. Experience in general is more passive than rational thought, but because surprise is based on our previous expectations and values, it may mean that sometimes we take some things (and not others) as surprising for good reason, although we did not muse with a plan to notice or be surprised in the way that we were. Of course, there is a difference between giving a rational explanation for why something was experienced as surprising (e.g. I noticed a sugar maple tree in the park, because I was thinking of planting one in my own yard), and giving a causal explanation for why something was surprising (e.g., I noticed that billboard because it was red and bright: it caught my eye). Here we mean a rational rather than a causal account for not just selecting some surprise as worth pursuing, but a rational account for even having the surprising experience itself. Reason is at work at all stages of musement, including in the very experiencing of surprising anomalies. ${ }^{16}$ And since Peirce's muser acts for reasons, some ideals must be at work. And since Peirce's muser does not set out to fulfill these 
ideals before musing, she must do so within this thought process in order to make these judgments. In musement one is open to these challenges and surprises without knowing exactly where the thought process will take her. When she sets out to muse, she sets out to reason in a way she did not plan. In addition to noticing, of course, there is the attraction to an idea that occurs in musement, as Anderson discusses, in the play of ideas in both art and science and, of course, in musement in the NA (Anderson, 1987: 110, 131). We allow ourselves to be attracted to an idea and this attraction to an idea is also a reflection of one's previously chosen ideals and values in addition to agape. So one's ideals influence the entire process of musement, even the initial stage of noticing.

\section{No Error in Musement}

We can understand musement as a creative thought process which does not proceed according to a pre-planned goal, and also understand musement as rational insofar as musement employs ideals and reasons internal to the activity of thinking itself. Yet there is another important sense in which musement does not fit the model of rational selfcontrol precisely, namely, musement does not err. There is no sense in which one can go wrong in musement qua musement precisely because musement doesn't have a goal neither an explicit goal in the mind of the muser, nor a goal hidden to the muser. One can muse and come up with incorrect hypotheses, of course, but this is not an error of musement in its primary mode of free play and noticing. ${ }^{17}$ At least at the noticing stage of musement, when one notices something strange, we cannot say that it is wrong to notice it or to find it surprising. ${ }^{18}$ Of course, it may seem strange to say that musement is evaluative, and yet cannot error. But the kind of evaluative claims that the individual makes in musement, especially at this noticing stage, are not truth claims, but claims regarding what is interesting, puzzling, and worth thinking about some more.

Yet, while we cannot muse according to a purpose and we cannot make errors in musement, we nonetheless can and do evaluate our musings retrospectively. And, in this sense, musement fits at least part of the model of self-control whereby we compare our past actions with our ideals and standards. So, while there may not be a way to have erroneous thoughts in musement, there is, nonetheless, a sense in which one might muse well or muse poorly. Both the noticing of anomalies and the hypothesis formation in musement can be more or less valuable, more or less novel, more or less relevant, more or less interesting, or even healthy. One may also have better or worse reasons for noticing what one does and selecting what one selects to ponder, and we may only be able to judge these reasons as more or less helpful, after musement is done. These judgments are made in light of ideals not necessarily at the forefront of our consciousness during musement. But although we may make judgments about the goodness or fruitfulness of musement only after musement has concluded, and although it is not the job of musement to be helpful, relevant, interesting, or true, this does not mean that the ideals we use to make those judgments were not at work during musement. While there may not be a purpose in musement, there are always ideals at work influencing the process, allowing the person to make the judgments she makes in her musement. And perhaps sometimes the reason why someone has more helpful, interesting, and relevant ideas when she muses is due to her ideals. One cannot muse without beliefs, values, and ideals already in place, even if she can suspend her immediate purpose. And again, one's values 
and beliefs influence what one notices, even if one attempts to neutralize one's beliefs, in Raposa's sense, so that she can muse relatively freely.

\section{BIBLIOGRAPHY}

ANDERSON Douglas, (1987), Creativity and the Philosophy of C. S. Peirce, Boston, Martinus Nijhoff Publishers, Kluwer Academic Publishers.

ANDERSON Douglas, (1995), Strands of System: The Philosophy of Charles Peirce, West Lafayette, Indiana, Purdue University Press.

BARNouw Jeffrey, (1988), “'Aesthetic' for Schiller and Peirce: A Neglected Origin of Pragmatism,” Journal of the History of Ideas, 49 (4), 607-32.

BARRENA Sara, (2013), "Reason and Imagination in Charles S. Peirce," European Journal of Pragmatism and American Philosophy, V (1). Online: [journals.openedition.org/ejpap/575].

BODEN Margaret, (2014), “Artificial Intelligence: A Contradiction in Terms?,” in Elliot Samuel Paul \& Scott Barry Kaufman (eds.), The Philosophy of Creativity. New Essays, New York, Oxford University Press.

COLLINGWOOD Robin George, (1958), The Principles of Art, New York, Oxford University Press. COOKE Elizabeth F., (2011), "Phenomenology of Error and Surprise: Peirce, Davidson, and McDowell," in Transactions of the Charles S. Peirce Society, 47 (1), 62-86.

DEWEY John, (2008), The Quest for Certainty, The Later Works, vol. IV, 1929, ed. Jo Ann Boydston \& Harriet Furst Simon, Carbondale, Southern Illinois University Press.

GAVA Gabriele, (2014), Peirce's Account of Purposefulness: A Kantian Interpretation, New York, Routledge.

HARRISON Andrew, (1971), "Creativity and Understanding," in Proceedings of the Aristotelian Society, vol. $45,95-121$.

HULL Kathleen, (1994), "Why Hanker After Logic? Mathematical Imagination, Creativity and Perception in Peirce's Systematic Philosophy," in Transactions of the Charles S. Peirce Society, XXX (2), 271-95

HULL Kathleen, (2005), “The Inner Chambers of his Mind: Peirce's 'Neglected Argument' for God as Related to Mathematical Experience," in Transactions of the Charles S. Peirce Society, XLI (3), 483-513.

JONES Royce, (1976), "Is Peirce's Theory of Instinct Consistently Non-Cartesian?," in Transactions of the Charles S. Peirce Society, XII (4), 348-66.

KEVELSON Roberta, (1999), Peirce and the Mark of the Gryphon, New York, St. Martin's Press.

KIERAN Matthew, (2014), "Creativity as a Virtue of Character," in Scott Barry Kaufman \& Elliot Samuel Paul (eds.), The Philosophy of Creativity, New York, Oxford University Press. 
LISZKA James, (2012), “Charles Peirce on Ethics," in Cornelis de Waal \& Krysztof Piotr Skowronski (eds.), The Normative Thought of Charles S. Peirce, New York, Fordham University Press.

MAITLAND Jeffrey, (1976), “Creativity,” Journal of Aesthetics and Art Criticism, 34 (4), 397-409.

PAPE Helmut, (2012), "Self-Control, Values, and Moral Development: Peirce on the Value-Driven Dynamics of Human Morality," in Cornelis de Waal \& Krzysztof Piotr Skowrońksi (eds.), The Normative Thought of Charles S. Peirce, New York, Fordham University Press.

PEIRCE Charles Sanders, (1931-1958), The Collected Papers of Charles Sanders Peirce, Cambridge, MA, Belknap Press of Harvard University Press. (Cited as CP.)

PEIRCE Charles Sanders, (1992), The Essential Peirce, volume 1, ed. Nathan Houser and Christian Kloesel, Bloomington, Indiana University Press. (Cited as EP1.)

PEIRCE Charles Sanders, (1998), The Essential Peirce, volume 2, ed. the Peirce Edition Project, Bloomington, Indiana University Press. (Cited as EP2.)

RAPOSA Michael L., (1989), Peirce's Philosophy of Religion, Bloomington, Indiana University Press.

RAPOSA Michael L., (2012a), "Musement as Listening: Daoist Perspectives on Peirce," Journal of Chinese Philosophy, 39 (2), 207-21.

RAPOSA Michael L., (2012b), "Love's Purposes, Hope's Necessity, and the God of Pragmaticism," in Cybernetics and Human Knowing: A Journal of Second-Order Cybernetics, Autopoiesis, and Cyber-Semiotics , Issue on The Scientific Metaphysics of C. S. Peirce, 19 (1-2), 47-57.

SANTAYANA George, (2009), Realms of Being, in The Essential Santayana, ed. The Santayana Edition, Bloomington, Indiana University Press.

SCHILLER Friedrich, (1884), Letters on the Æsthetical Education of Man, Letter XVII, in The Works of Frederick Schiller, vol. IV, New York, John W. Lovell Company.

SHORT T. L., (2004), "The Development of Peirce's Theory of Signs," in Cheryl Misak (ed.), The Cambridge Companion to Peirce, Cambridge, Cambridge University Press, 214-40.

SHORT T. L., (2007), Peirce's Theory of Signs, Cambridge, Cambridge University Press.

\section{NOTES}

1. Schiller (1884: 120).

2. See Jeffrey Barnouw 1988. Barnouw argues the early influence of Schiller on Peirce extends throughout Peirce's writings. In particular, Barnouw argues that the root of Peirce's reasoning as self-control is a habit of feeling, which has been subjected to self-criticism, and this Peirce gets from Schiller. As Barnouw writes (ibid.: 609), “Aesthetics so conceived is a discipline governing the deliberate formation of habits of feeling which should inform our responses, our readiness to act in particular ways given particular circumstances. This is the main respect in which Friedrich Schiller's conception of aesthetic education as cultivation of the capacity of feeling (Ausbildung des Empfindungsvermögens) should be seen as an influential model for Peirce."

3. See also Roberta Kevelson (1999: 220). She discusses Peirce's view on how we might indirectly control creativity and induce novelty (ms. 1105) "by deliberately distorting the means by which we habitually, consciously transform sensibility into thought" (Kevelson, 1999: 220).

4. See Helmut Pape (2012: 159). Here Pape argues that self-control, for Peirce, does not entail controlling oneself at a particular moment, but is an ongoing process, which entails both 
prospective anticipation and retrospective reflections in comparing one's actions with one's ideals (CP8.320).

5. This same passage appears in George Santayana's Realms of Being (2009: 152): "Spirit bloweth where it listeth, and continually undoes its own work."

6. See also Anderson (1987: 42).

7. See also Royce Jones (1976: 357); and Sara Barrena (2013: 12).

8. According to Gabriele Gava in Peirce's Account of Purposefulness: A Kantian Interpretation (2014), purposefulness is a necessary condition for semiosis. Gava argues that the metaphysics of cosmology and growth depend upon Peirce's account of the necessity of purpose in thinking and sign processes (and not the other way around, like other scholars argue) (ibid.: 2).

9. For example, Margaret Boden in "Artificial Intelligence: A Contradiction in Terms?" discusses several kinds of creativity, one of which she calls transformational creativity because the novel structure does not fit into previously known styles. In these cases "the originator alters (or drops) some previously recognized constraint or adds one or more new ones." But Boden does not discuss the thought process whereby someone notices there was a constraint there to begin with (2014: 228-9).

10. Michael Raposa in "Musement as Listening: Daoist Perspectives on Peirce," emphasizes listening over looking since it is more passive (2012a: 214). See also Anderson (1995: 148) who also discusses the phenomenological and perceptive part of musement as well as the internal dialogue and diagrammatic part of musement.

11. See Kevelson's discussion of this passage in her discussion on musement and creativity (1999: 221).

12. See Raposa (1989: 125). See also Hull (2005: 493), and Kevelson (1999: 219).

13. Short in Peirce's Theory of Signs (2007: 154) argues that wherever there is purpose, there can be success or failure, better or worse, and thus, self-correction, but without purpose, there can be no mistakes. Similarly, James Liszka in "Charles Peirce on Ethics," (2012: 56) also argues that purposive action and rational self-control go together, and that without the possibility of error and self-correction, it is difficult to see how there can be self-control.

14. Anderson sees his interpretation as evidence that Peirce held the claim we find in contemporary aesthetics that an artist does not know fully what he is going to create until he creates it (ibid.: 5-6). See also Collingwood who argues in The Principles of Art (1958) that true creative art (as opposed to craft) cannot have a preplanned goal in mind beforehand - otherwise it is not true creativity (ibid.: 129). See also Maitland (1976: 397); Kieran (2014: 127, 129); and Harrison (1971: 111-2, 115, 118).

15. I am grateful to R. Abrams for this example.

16. Hull argues that in one sense both musement and mathematical reasoning are not selfcontrolled logics because they are semiotic or interpretive activities, not rule-following activities. But Musement, like mathematics, is an observational activity. But Hull (1994: 286) thinks it is still rationally self-controlled, because she reads Peircean self-control as being inhibitory in the sense of controlling the self so that we may perceive genuine Thirdness (in the mathematical diagram).

17. It may be argued that, at later stages of musement, which might take on a purpose of explaining some anomaly, musement can be said to go wrong, because it can go right, as Peirce claims musement can provide the "smoothly fitting keys" to problem (EP2:437).

18. Of course, surprise itself is the discovery of an error in a previous belief or expectation. But the discovery of an error is not itself an error but rather an achievement. See Cooke 2011. 


\section{ABSTRACTS}

An apparent tension persists in Peirce's philosophy between the purpose-driven nature of inquiry, destined to achieve truth in the long run, on the one hand, and, on the other hand, the fact that inquiry depends upon musement (or the free play of ideas), which is purposeless. If there is no purpose in musement then it would appear there is no rational self-control in musement, and thus, irrationality lies at the center of Peirce's theory of inquiry. I argue that in musement the individual sets off without a purpose, thereby opening herself to noticing novelty, and that noticing is itself a form of creative thought insofar as it allows the individual to discover new wonders and anomalies. Not all creativity in inquiry aims at solving problems or formulating new hypotheses. Some creative thinking is about noticing what is already there or possibly there. Such noticing in musement is purposeless, and yet the individual retains some rational selfcontrol within this thought process. She controls the entry into the activity, and, prior to musing, she controls the adoption of the ideals which are inevitably employed in musement. This adoption of some ideals rather than others can explain why some people notice things while others do not.

\section{AUTHOR}

\section{ELIZABETH F. COOKE}

Creighton University

efc09574[at]creighton.edu 